\title{
PENINGKATKAN PERILAKU SOSIAL KEAGAMAAN PESERTA DIDIK KELAS 6 SDN SIMOMULYO I SURABAYA MELALUI PENERAPAN PENDIDIKAN AGAMA ISLAM
}

\author{
M. S. Badar \\ Prodi Pendidikan Agama Islam, STIT Al-Urwatul Wutsqo Jombang \\ e-mail:ms_badar@yahoo.co.id
}

\begin{abstract}
This PTK study is motivated by the existence of religious activities at SDN Simomulyo I Surabaya such as tartil suroh-suroh juz 'amma, chanting Asmaul Husna, congregational prayer and infaq. These problems were discussed through field study research conducted in grade 6 SDN Simomulyo I Surabaya, with 36 students as respondents. Meanwhile, the data collection method used questionnaires, observation and documentation. The data were obtained by distributing questionnaires with a total of 30 questions and given to 36 students in grade 6 . All data were analyzed using a quantitative approach and descriptive statistical analysis. The study shows that: (1) The application of Islamic religious education for 6th grade students of SDN Simomulyo I Surabaya has an average value of $=41.31$. This shows that the intensity of students in participating in religious activities is in the High category, which is in the value interval 31-45. (2) The socio-religious behavior of grade 6 students at SDN Simomulyo I Surabaya has an average value of $=37.83$. This shows that the socio-religious behavior of students is included in the High category, which is in the value interval 31 - 45. (3) There is an influence of variable X (Implementation of Islamic Education) on variable Y (Religious Social Behavior of Class 6 SDN Simomulyo Students. I Surabaya). Thus it can be said that there is a positive and significant influence between the application of Islamic religious education on the socio-religious behavior of students in grade 6 SDN Simomulyo I Surabaya is accepted.
\end{abstract}

Keywords: PAI, Religious Social, Students

\section{PENDAHULUAN}

Seiring perkembangan zaman, pendidikan agama Islam pada lembaga pendidikan harus diposisikan sebagai program andalan dan ruh bagi pembentukan moralitas peserta didik. Dengan kata lain, Pendidikan Agama Islam perlu diposisikan sebagai 'rasul pembangunan bangsa' yang misi utamanya pembangunan watak, pembinaan akhlak, pendidikan moral atau pendidikan nilai. ${ }^{1}$

Pendidikan agama Islam tidak hanya tampil dan berperan sebagai pemberi pegangan hidup dilevel masing-masing individu, tetapi juga sebagai pemberi kesejukan

1 Sanapiah Faisal, Rekonstruksi Pendidikan Agama Sesuai Tuntutan Era Reformasi, Qua V adis Pendidikan Islam (Malang: Cendekia Paramulya,2002), 46 
dan keselamatan bagi kehidupan masyarakat, bangsa dan negara secara keseluruhan. Namun demikian, akhir-akhir ini banyak pihak yang mempertanyakan tentang efektifitas pendidikan agama apabila dikaitkan dengan gejala degradasi moral atau kekeringan nilai dikalangan masyarakat.

Faktanya masih banyak korupsi yang dilakukan oleh tokoh masyarakat atau negara yang menjadi figur atau teladan, meningkatnya tingkah laku kekerasan dari para remaja dan pemuda (sikap arogan), ketidakjujuran, pencurian, krisis kewibawaan, menurunnya etos dan etika kerja, penyelewengan seksual, meningkatnya egoisme dan menurunnya tanggung jawab warga negara ditambah lagi beberapa tahun terakhir ini tawuran antar pelajar dan remaja sering kali terjadi.

Jika dibandingkan dengan 20 atau 30 tahun lalu, para remaja sekarang semakin maju. Kebanyakan remaja kini tidak lagi anti sosial, yang hanya mau duduk di perpustakaan membaca buku tanpa mau berhubungan dengan dunia luar. Mereka justru membuat pergaulan seluas mungkin yang mereka bisa, karena zaman sekarang ini dengan cara itulah mereka bisa benar-benar dikenal oleh banyak orang. Mulai dari berkenalan lewat tempat les, dunia maya, forum sampai lewat suatu komunitas tertentu.

Masalah sosial juga dirasakan dalam dunia pendidikan, masalah pendidikan dalam keluarga, pendidikan di sekolah dan pendidikan dalam masyarakat. Kenakalan remaja juga merupakan salah satu bentuk masalah sebagai akibat dari perubahan sosial ${ }^{2}$. Kenakalan remaja dalam studi masalah sosial dan keagamaan dapat dikategorikan ke dalam perilaku menyimpang. Dalam perspektif perilaku dari berbagai aturan-aturan sosial dan keagamaan ataupun dari nilai dan norma sosial yang berlaku. Perilaku menyimpang dapat membahayakan tegaknya sistem sosial.

Sampai saat ini pelaksanaan pendidikan agama Islam di sekolah masih menghadapi berbagai tantangan baik internal maupun eksternal. Secara internal, Pendidikan Agama Islam di sekolah masih dianggap kurang berhasil dalam membentuk sikap dan perilaku sosial keagamaan peserta didik. Secara eksternal Pendidkan Agama Islam masih menghadapi tantangan yang berupa menguatnya pengaruh budaya-budaya asing non edukatif yang bersifat global seperti materialisme, konsumerisme dan hedonisme, sehingga menjadi gaya hidup (life style) masyarakat dan peserta didik pada

${ }^{2}$ Ramli Atmasasmita, Problem Kenakalan Anak/Remaja: Juridis, Sosio, Kriminologi (Bandung: Armico, 1984), 54 
umumnya, kenyataan seperti inilah yang sulit dibendung, maka penerapan pendidikan agama diharapkan menjadi budaya (religious culture) ekolah dan lingkungan tempat tinggal mereka. Berdasarkan masalah tersebut, menjadi tantangan yang sangat besar bagi penerapan pendidikan agama Islam untuk perbaikan perilaku peserta didik.

\section{PEMBAHASAN}

\section{A. Penerapan Pendidikan Agama Islam Di SDN Simomulyo I Surabaya.}

Penerapan pendidikan agama Islam dalam hal ini diartikan sebagai pelaksanaan atau pembiasaan pendidikan agama Islam (PAI) yang mengarah pada internalisasi nilai-nilai karakter dalam tingkah laku sehari-hari melalui kegiatan belajar mengajar (KBM) di kelas maupun di luar kelas dengan beberapa tahap, yakni tahap perencanaan, pelaksanaan dan evaluasi (penilaian).

\section{Tahap Perencanaan}

Pada tahap ini, penulis mencantumkan data melalui proses pembuatan perangkat pembelajaran baik dari silabus maupun rencana pelaksanaan pembelajaran (RPP). Perangkat pembelajaran tersebut mencantumkan nilainilai karakter yang ada dalam materi pembelajaran ke dalam silabus dan RPP. Oleh karena itu, terkait penyusunan perangkat pembelajaran baik silabus dan RPP, penulis mengacu pada kurikulum 2013 (KURTILAS) dengan format KI1 (Sikap Religius), KI-2 (Sikap Sosial), KI-3 (Pengetahuan) dan KI-4 (Ketrampilan) dengan pencantuman nilai-nilai karakter dan budaya bangsa Indonesia secara tertulis sebagai wujud dari penjabaran dari visi dan misi SDN Simomulyo I Surabaya.

2. Tahap Pelaksanaan/Proses

Untuk mengetahui bagaimana pengaruh penerapan pendidikan agama Islam di SDN Simomulyo I Surabaya, khususnya pada proses pembelajaran di kelas, penulis selain mengadakan observasi dan wawancara, penulis juga menggunakan angket kepada peserta didik untuk memperoleh data yang akurat dan objektif. Pada tahap proses ini terbagi menjadi dua, antara lain :

a) Di Kelas

Dari hasil pengamatan atau observasi yang penulis lakukan, akhirnya dapat menggambarkan situasi dan kondisi proses belajar mengajar. Pertama, 
observasi dilakukan penulis pada kelas 6-A, adapun gambaran proses pembelajarannya sebagai berikut: Pada saat pertama masuk kelas, peserta didik langsung melakukan penghormatan kepada guru. Dilanjutkan dengan guru mengucapkan salam dan mengondisikan peserta didik untuk mengikuti pelajaran, selanjutnya mengabsen peserta didik dan mengajak peserta didik berdoa sebelum belajar, membaca surah-surah pendek (juz 'amma) serta melantunkan Asmaul Husna. Setelah itu guru menjelaskan indikator/tujuan yang harus dicapai.

Untuk pertemuan dengan alokasi waktu dua jam pelajaran maka pada satu jam pertama di gunakan untuk menjelaskan materi ajar kepada siswa dan untuk satu jam berikutnya digunakan untuk presentasi dan diskusi kelompok. Dalam penyampaian materi ajar metode yang digunakan adalah ceramah, tanya jawab, drill dan demonstrasi. Kemudian penulis memberikan waktu peserta didik untuk bertanya mengenai materi yang belum difahami.

Sebelum mengakhiri pelajaran, langkah yang dilakukan yakni menanyakan ulang apa yang telah dipelajari peserta didik mulai awal sampai akhir pelajaran. Proses ini dilakukan untuk mengetahui tingkat pemahaman peserta didik dalam mengikuti kegiatan belajar mengajar di kelas. Pada alokasi waktu satu jam berikutnya digunakan untuk diskusi (Drill) perkelompok dan presentasi, maka dilanjutkan dengan pemaparan hasil diskusi perkelompok ke depan kelas. Setelah selesai pemaparan maka dilakukan proses tanya jawab yang dipandu oleh guru PAI. Selama proses tanya jawab ini, guru mengamati jalannya proses diskusi dan melakukan penilaian kinerja peserta didik yang ada dalam proses diskusi dan presentasi.

Setelah selesai presentasi dan diskusi, guru melakukan konfirmasi kepada peserta didik mengenai proses jalannya diskusi, sehingga dalam kelas tersebut diperoleh pemahaman yang sama mengenai materi pelajaran yang telah dilakukan. Kemudian pada kegiatan penutup, peserta didik diberikan tugas mandiri (PR), kemudian sebelum mengakhiri pelajaran dilakukan pembinaan dan penyadaran tentang karakter-karakter yang harus di miliki peserta didik 
b) Di Luar Kelas

Untuk membiasakan siswa supaya mempunyai karakter berakhlak mulia, maka dalam proses belajar mengajar akan lebih baik jika pembelajaran tersebut dilaksanakan secara bersambung dan bertahap dari pembelajaran di dalam kelas ke penerapan di luar kelas. Pada penerapan di luar kelas ini lebih diorientasikan pada pembinaan perilaku sosial keagamaan peserta didik. Pada proses di luar kelas ini dapat dikatakan sebagai tindak lanjut dari pengamatan di kelas atau temuan guru mengenai sikap dan perilaku peserta didik. Metode atau strategi yang digunakan adalah nasehat, keteladanan, pembiasaan dan pendekatan terhadap masing-masing peserta didik. misalnya, untuk membiasakan mengikuti kegiatan sholat jama'ah, hal yang dilakukan guru PAI adalah dengan melakukan kontrol setiap kelas dan mengajak peserta didik untuk terbiasa mengikuti kegiatan salat jama’ah.

3. Tahap Evaluasi

Evaluasi (penilaian) merupakan hal yang paling penting dilakukan oleh seorang guru untu pengukuran ketercapaian program pembelajaran yang telah dilakukan dalam kegiatan belajar mengajar di kelas maupun di luar kelas. Evaluasi (penilaian) yang dilakukan oleh guru dalam rangka penerapan PAI berkarakter di SDN Simomulyo I Surabaya merasa kesulitan dalam melakukan penilaian atau evaluasi yang berdasarkan pendidikan karakter. Untuk penilaian yang dilakukan oleh guru, sementara ini masih lebih banyak pada penilaian di kelas (penilaian ketika proses kegiatan belajar mengajar). Untuk di luar kelas guru melakukannya dengan pengamatan atau pemantauan yang mengarah pada pembinaan akhlak (perilaku) siswa.

\section{ANALISIS}

\section{A. Tahap Perencanaan}

Perencanaan pembelajaran adalah proses penyusunan materi pelajaran, penggunaan media pembelajaran, penggunaan pendekatan atau metode pembelajaran, dalam suatu alokasi waktu yang akan dilaksanakan pada masa satu semester yang akan datang untuk mencapai tujuan yang telah ditentukan. Proses 
perencanaan pembelajaran meliputi silabus dan rencana pelaksanaan pembelajaran (RPP) yang memuat identitas mata pelajaran, KI-1, KI-2, KI-3 dan KI-4, indikator pencapaian kompetensi, tujuan pembelajaran, materi ajar, alokasi waktu, metode pembelajaran, kegiatan pembelajaran, penilaian hasil belajar, dan sumber belajar ${ }^{3}$. Pada tahap perencanaan pembelajaran, ada beberapa langkah yang dilakukan oleh guru dalam rangka penerapan pendidikan agama Islam berkarakter, antara lain :

1. Melakukan pemahaman tentang visi dan misi sekolah agar tujuan dalam pencapaian karakter yang muncul menjadi ciri khas sekolah.

2. Semua guru PAI melakukan diskusi bersama untuk memperoleh kesepakatan dalam memetakan nilai-nilai karakter yang akan diterapkan kepada peserta didik.

3. Secara bersama-sama guru melakukan analisis SKL, KI-1, KI-2, KI-3, KI-4 dan bahan ajar. Kemudian dari proses tersebut akan ditentukan indikator pencapaian hasil pembelajaran dan nilai nilai karakter yang akan di integrasikan dalam proses pembelajaran.

4. Memasukkan nilai-nilai karakter tersebut dalam perangkat pembelajaran yakni pada silabus dan RPP dengan format kegiatan sesuai dengan PERMENDIKBUD No. 20, 21, 22, 23 dan 24 tahun 2016 tentang standar kompetensi lulusan, standar isi, standar dikdasmen, standar penilaian dan standar KI-KD.

Pemaparan tersebut selaras dengan penjelasan Umi Kulsum dalam bukunya yang berjudul implementasi pendidikan karakter berbasis PAIKEM. Dalam pengembangan nilai-nilai karakter melalui pengintegrasian dalam mata pelajaran ada beberapa cara, sebagai berikut:

1. Mengkaji standar kompetensi (SK) dan kompetensi dasar (KD) untuk menentukan apakah kandungan nilai-nilai dan karakter yang secara tersirat atau tersurat dalam SK dan KD diatas sudah tercakup didalamnya.

2. Menggunakan tabel 1 yang memperlihatkan keterkaitan antara SK/KD dengan nilai dan indikator untuk menentukan nilai yang akan dikembangkan.

3. Mencantumkan nilai-nilai dan karakter bangsa ke dalam silabus.

4. Mencantumkan nilai-nilai yang sudah tercantum dalam silabus ke RPP

${ }^{3}$ Syamsul Hadi, https://www.maribelajarbk.web.id/2018/06. 
5. Mengembangkan proses pembelajaran peserta didik aktif, inovatif, kreatif, efektif dan menyenangkan yang memungkinkan peserta didik memiliki kesempatan melakukan internalisasi nilai dan menunjukkannya dalam perilaku.

6. Memberikan bantuan kepada peserta didik yang mengalami kesulitan untuk internalisasi nilai maupun untuk menunjukkannya dalam perilaku.

\section{B. Tahap Proses Pembelajaran}

Sesuai dengan hasil observasi lapangan dan wawancara bahwa dalam penerapan pembelajaran terutama pada tahap proses terbagi menjadi dua, sebagai berikut :

1. Pembelajaran Kelas

Berdasarkan pemaparan data hasil wawancara dan observasi, bahwa dalam penerapan pendidikan agama Islam di kelas pendidik menggunakan model pembelajaran kooperatif dengan berbagai tipe yakni TPS (berpasang-pasangan), JIGSAW, video coment. Ketika proses pembelajaran, peserta didik melakukan diskusi atau kerja secara kelompok, ketika diskusi peserta didik secara bersama saling bertukar pengetahuan sehingga ditemukan suatu kesepakatan tentang suatu masalah yang diberikan oleh pendidik untuk diselesaikan oleh setiap kelompok. Metode yang digunakan adalah metode ceramah, nasehat, demonstrasi dan cerita.

Sedangkan media yang digunakan oleh guru adalah slide power point (PPT) dengan alat LCD proyektor. Hal tersebut sesuai dengan pendapat Thomas Lickona dalam buku yang ditulis oleh Zubaedi yang berjudul desain pendidikan karakter, konsepsi dan aplikasinya dalam lembaga pendidikan. Menurut Thomas Lickona, pendidikan karakter amat cocok dengan disajikan dengan format pembelajaran kooperatif (cooperative learning). Hal ini menyadari karakteristik pendidikan karakter yang lebih terfokus untuk membangun insan yang bisa hidup secara sosial dengan keterampilan sosial (soft skill) yang dimiliki. Mengajar dengan model pembelajaran kooperatif akan memungkinkan pendidik dapat mengajarkan nilai-nilai atau karakter dan akademik secara bersamaan ${ }^{4}$.

4 Zubaedi, Desain Pendidikan Karakter: Konsepsi dan Aplikasinya dalam Lembaga Pendidikan, Jakarta: Kencana, 2011), 214-215 
2. Pembelajaran di luar kelas

Untuk membiasakan peserta didik supaya mempunyai karakter berakhlak mulia, maka dalam proses belajar mengajar akan lebih baik jika pembelajaran tersebut dilaksanakan secara berkesinambungan dan bertahap dari pembelajaran di dalam kelas ke penerapan di luar kelas, pendidik lebih menekankan pada pembinaan perilaku peserta didik. Kegiatan-kegiatan yang menjadi ukuran dalam pembinaan perilaku peserta didik adalah kegiatan shalat berjama'ah, kegiatan membaca Alqur'an dan berinfaq setiap Jum'ah..

Dalam pembinaan perilaku peserta didik, upaya yang dilakukan pendidik adalah dengan mengembangkan tradisi spiritual yang tinggi terhadap peserta didik dengan memberikan tauladan yang baik terutama dalam bertutur kata dan berperilaku. Hal ini di lakukan di kelas dan di luar kelas. Seperti mengaji dan berdoa sebelum dan sesudah pelajaran. Untuk mengembangkan tradisi spiritual sehingga menjadi karakter sekolah yang islami, guru juga melakukannya dalam kegiatan-kegiatan peringatan hari besar Islam. Seperti tercermin pada kegiatan peringatan tahun baru hijriyah, maulid Nabi Muhammad saw., isra' mi'raj, dan pesantren ramadhan.

Untuk melakukan pembinaan kepada siswa yang notabene bisa dikatakan nakal, maka guru melakukannya dengan pendekatan secara personal kepada yang bersangkutan. Kemudian setelah melakukan pendekatan tersebut maka guru akan memberikan nasehat-nasehat keagamaan, keteladanan dalam berbuat dan bersikap.

\section{C.Tahap Evaluasi/Penilaian}

Berdasarkan hasil observasi dan dokumentasi, dalam melakukan penilaian hasil dalam pelaksanaan penerapan pendidikan agama Islam, guru melakukan penilaian dengan dua penilaian, antara lain :

1. Penilaian Dalam Kelas

Adapun mengenai penilaian dalam kelas, guru menggunakan teknik penilaian sebagai berikut: 
a. Tes tulis, baik dengan bentuk obyektif (pilihan ganda, benar salah dan menjodohkan), non obyektif (Jawaban singkat atau isian singkat), dan soal uraian.

b. Penilaian kinerja

c. Penilaian portofolio

d. Penilaian sikap (performance)

2) Penilaian di luar kelas

Adapun mengenai penilaian di luar kelas, pendidik lebih menekankan pada pengamatan sikap peserta didik dalam berkata, bersikap dan berperilaku kepada sesama peserta didik dan kepada bapak ibu guru. Pemaparan tersebut sejalan dengan apa yang tercantum dalam buku pengembangan pendidikan dan karakter bangsa yang diterbitkan oleh Kementrian Pendidikan Nasional. tentang penilaian hasil belajar, dalam redaksi yang sama dijelaskan oleh Umi Khulsum, dalam bukunya Implementasi Pendidikan Karakter Berbasis PAIKEM, bahwa penilaian pencapaian nilai nilai karakter didasarkan pada indikator pencapaian hasil.

Sebagai contoh, indikator untuk nilai jujur di suatu semester dirumuskan dengan "mengatakan dengan sesungguhnya perasaan dirinya mengenai apa yang dilihat, diamati, dipelajari, atau dirasakan" maka guru mengamati (melalui berbagai cara) apakah yang dikatakan seorang peserta didik itu jujur mewakili perasaan dirinya. Mungkin saja peserta didik menyatakan perasaannya itu secara lisan tetapi dapat juga dilakukan secara tertulis atau bahkan dengan bahasa tubuh.

Perasaan yang dinyatakan itu mungkin saja memiliki gradasi dari perasaan yang tidak berbeda dengan perasaan umum teman sekelasnya sampai bahkan kepada yang bertentangan dengan perasaan umum teman sekelasnya. Penilaian dilakukan secara terus menerus, setiap saat guru berada di kelas atau di sekolah.

Model anecdotal record (catatan yang dibuat guru ketika melihat adanya perilaku yang berkenaan dengan nilai yang dikembangkan) selalu dapat digunakan guru. Selain itu, guru dapat pula memberikan tugas yang berisikan suatu persoalan atau kejadian yang memberikan kesempatan kepada peserta didik untuk menunjukkan nilai yang dimilikinya. 
Sebagai contoh, peserta didik diminta menyatakan sikapnya terhadap upaya menolong pemalas, memberikan bantuan terhadap orang kikir, atau halhal lain yang bersifat bukan kontroversial sampai kepada hal yang dapat mengundang konflik pada dirinya. Dari hasil pengamatan, catatan anekdotal, tugas, laporan, dan sebagainya, guru dapat memberikan kesimpulan atau pertimbangan tentang pencapaian suatu indikator atau bahkan suatu nilai.

Kesimpulan atau pertimbangan itu dapat dinyatakan dalam pernyataan kualitatif sebagai berikut ini :

BT : Belum Terlihat (apabila peserta didik belum memperlihatkan tanda-tanda awal perilaku yang dinyatakan dalam indikator).

MT : Mulai Terlihat (apabila peserta didik sudah mulai memperlihatkan adanya tanda-tanda awal perilaku yang dinyatakan dalam indikator tetapi belum konsisten).

MB : Mulai Berkembang (apabila peserta didik sudah memperlihatkan berbagai tanda perilaku yang dinyatakan dalam indikator dan mulai konsisten).

MK : Membudaya (apabila peserta didik terus menerus memperlihatkan perilaku yang dinyatakan dalam indikator secara konsisten).

Pernyataan kualitatif di atas dapat digunakan ketika guru melakukan asesmen pada setiap kegiatan belajar sehingga guru memperoleh profil peserta didik dalam satu semester tentang nilai terkait (jujur, kerja keras, peduli, cerdas, dan sebagainya). Guru dapat pula menggunakan BT, MT, MB atau MK tersebut dalam rapor ${ }^{5}$.

Untuk menganalisis hasil angket bahwa rata-rata penerapan Pendidikan Agama Islam dan perilaku peserta didik di SDN Simomulyo I Surabaya dapat digunakan rumus mean.

a. Untuk menganalisis rata-rata penerapan Pendidikan Agama Islam di SDN Simomulyo I Surabaya dapat digunakan rumus Mean.

$$
\mathrm{M}_{\mathrm{x}}=\frac{\Sigma \mathrm{X}}{N}
$$

${ }^{5}$ Hamid Hasan, Said, Pengembangan Pendidikan Budaya dan Karakter Bangsa Jakarta: Puskur Balitbang Kemendiknas, 2010), 22-23 


$$
\begin{aligned}
& M_{x}=\frac{1487}{36} \\
& M_{x}=41,31
\end{aligned}
$$

Interpretasi : Dari data yang telah diperoleh rata-rata penerapan Pendidikan Agama Islam kelas 6 di SDN Simomulyo I Surabaya yang terdiri dari jumlah skor dibagi dengan jumlah sampel yang diteliti menghasilkan 41,31. Nilai ini termasuk kategori "Tinggi”

b. Untuk menganalisis rata-rata perilaku peserta didik kelas 6 di SDN Simomulyo I Surabaya dapat digunakan rumus Mean.

$$
\begin{aligned}
& \mathrm{M}_{\mathrm{x}}=\frac{\Sigma \mathrm{Y}}{N} \\
& \mathrm{M}_{\mathrm{x}}=\underline{1362} \\
& 36 \\
& \mathrm{M}_{\mathrm{x}}=37,83
\end{aligned}
$$

Interpretasi : Dari data yang telah diperoleh rata-rata perilaku sosial keagamaan peserta didik kelas 6 di SDN Simomulyo I Surabaya yang terdiri dari jumlah skor dibagi dengan jumlah sampel yang diteliti menghasilkan 37,83. Nilai ini termasuk kategori "Tinggi"

c. Untuk menganalisis pengaruh penerapan pendidikan agama Islam terhadap perilaku peserta didik terlebih dahulu dibuat tabel kerja kemudian dilanjutkan dengan perhitungan rumus product-moment. Setelah itu disajikan interpretasi dan kesimpulannya.

\section{Rekapitulasi Hasil Penelitian dan Pembahasannya}

1. Rekapitulasi hasil penelitian, sebelum dilakukan pembahasan terhadap temuantemuan penelitian ini, maka perlu disajikan terlebih dahulu rangkuman hasil-hasil penelitian.

2. Pembahasan temuan hasil penelitian

a. Bahwa hasil penelitian menunjukkan "dari data yang telah diperoleh rata-rata penerapan pendidikan agama Islam kelas 6 di SDN Simomulyo I Surabaya termasuk kategori "tinggi”. 
b. Bahwa hasil penelitian menunjukkan "dari data yang telah diperoleh rata-rata perilaku sosial keagamaan peserta didik kelas 6 di SDN Simomulyo I Surabaya termasuk kategori "tinggi".

c. Bahwa hasil penelitian menunjukkan "ada korelasi positif yang signifikan antara penerapan pendidikan agama Islam dengan perilaku sosial keagamaan pada diri peserta didik kelas 6 di SDN Simomulyo I Surabaya dalam kategori "sangat kuat".

\section{KESIMPULAN}

Penerapan pendidikan agama Islam sudah berjalan dengan baik dibuktikan dengan adanya perangkat pembelajaran berdasarkan hasil observasi, wawancara dan angket. Adapun pelaksanaan pembelajaran PAI sudah cukup baik, berdasarkan data angket yang menunjukkan bahwa respon peserta didik terhadap pembelajaran yang telah dilakukan oleh guru dalam kategori “Tinggi”. Sebagaimana analisis data dari sampel 36 anak bila dirata-rata nilainya 41,31. Deskripsi tentang perilaku peserta didik di SDN Simomulyo I Surabaya berdasarkan pengambilan angket bila dirata-rata nilainya 37,83. Nilai ini termasuk kriteria “Tinggi”. Sehingga dapat dideskripsikan bahwa keadaan perilaku social keagamaan peserta didik sudah baik. Ada pengaruh yang signifikan antara penerapan pendidikan agama Islam dengan perilaku sosial keagamaan peserta didik kelas 6 di SDN Simomulyo I Surabaya, bahwa masih sangat kuat pengaruh dari penerapan pendidikan agama Islam terhadap perubahan perilaku sosial keagamaan peserta didik.

\section{DAFTAR PUSTAKA}

Faisal , Sanapiah, Rekonstruksi Pendidikan Agama Sesuai Tuntutan Era Reformasi, Qua Vadis Pendidikan Islam, Malang: Cendekia Paramulya, 2002

Atmasasmita, Ramli, Problem Kenakalan Anak/Remaja: Juridis, Sosio, Kriminologi (Bandung: Armico, 1984.

Hadi, Syamsul, https://www.maribelajarbk.web.id/2018/06.

Zubaedi, Desain Pendidikan Karakter: Konsepsi dan Aplikasinya dalam Lembaga Pendidikan, Jakarta: Kencana, 2011. 
Said, Hamid Hasan, Pengembangan Pendidikan Budaya dan Karakter Bangsa, Jakarta: Puskur Balitbang Kemendiknas, 2010. 